American Journal of Applied Sciences 2 (13): 39-44, 2005

ISSN 1546-9239

(C) 2005 Science Publications

\title{
Imperfectly-Rational Agents, Volatility of Reserves and Customer Markets
}

\author{
${ }^{1}$ Partha Gangopadhyay and ${ }^{2}$ Renu Gangopadhyay \\ ${ }^{1}$ School of Economics and Finance, University of Western Sydney, Campbelltown Campus \\ Locked Bag 1797, NSW 1797, Australia \\ ${ }^{2}$ Sydney Harbour Foreshore Authority, 66 Harrington Street, The Rocks, NSW 2000, Australia
}

\begin{abstract}
Potential customers in customer markets are typically dichotomised into actual and prospective customers. If the firm holds its price firm, the actual customers hold their reserves/reservation price firm and repeat their purchases. On the other hand, prospective customers' reserves may be volatile due to their non-equilibrium market experience. One may regard a prospective buyer with a volatile reserve as imperfectly rational. On the other hand, one may suppose that an actual customer with a firm reserve is fully rational. We examine this hitherto-neglected asymmetry in customer markets to highlight that a firm can use imperfectly rational and prospective customers-characterised by their volatile reserves-as a European option. As the volatility increases, so does the value of the option of selling the products to the prospective customers. We also establish that volatility of reserves and hence imperfection in rationality of buyers, can have positive impact on output and employment in customer markets.
\end{abstract}

Key words: Customer market, reserves, relative risk aversion, options

\section{INTRODUCTION}

Customer markets are typically characterised by information asymmetry Scitovsky ${ }^{[1]}$, Stiglitz ${ }^{[2]}$ customers are fully aware of the price of their patronised firm, but less aware of the prices of other firms. Formal models of customer markets have adequately addressed this asymmetry ${ }^{[3-6]}$. Some of these models examine the effects of unanticipated shock on the pricing policy of a firm in a customer market. If a firm raises its price-following a positive price shockall of its customers whose reserves/reservation price are less than the new price will instantly disappear. This will cause an upward movement of the concerned firm along the demand function. However, if the firm reduces its price, potential customers take a while to discover the price change that causes a downward rigidity in demand function. The upshot is that the marginal revenue function has a discontinuity that can explain rigidity of prices in such markets ${ }^{[12]}$. Stiglitz ${ }^{[2]}$ analysed static search markets with homogenous goods to predict similar discontinuity in firms' marginal revenue functions $)^{[6,7]}$. Such information asymmetry naturally causes asymmetry in customer flows. The sluggish customer flows cause demand uncertainty that, in turn, induces firms to seek loyalty of repeat-buyers by insulating them from random shocks in demand and cost functions ${ }^{[8,9]}$. Customers have an incentive to offer loyalty due to switching $\operatorname{cost}^{[10]}$, or because of information asymmetry ${ }^{[1,2,11]}$.

The primary purpose of this work is to highlight another type of asymmetry that characterises customer markets if the market fails to achieve an instantaneous equilibrium: actual customers of the patronised firm have inflexible reservation prices (hereafter, reserves) so long as the firm does not change its price. Some of the potential customers, on the contrary, may have "flexible reserves" that are hinged on their experiences with other firms. This may be caused by the disequilibrium nature of the market in which some buyers are still learning about the market prices. One may choose to call this second type of buyers as imperfectly rational who are still updating their reserves with the unfolding of their market experiences.

It is customary in this literature to dichotomise customers into two groups, namely, actual and prospective customers: Given the prices, the potential customers are defined as those buyers who would patronise the concerned firm if these buyers have perfect information. Actual customers of a firm are the potential customers who are currently patronising the firm. Prospective customers are the rest of the potential customers who are either shopping with other firms, or outside the market, or just watching how the market unravels. If the learning experience

Corresponding Author: Partha Gangopadhyay, School of Economics and Finance, University of Western Sydney, Campbelltown Campus, Locked Bag 1797, NSW 1797, Australia 
of prospective customers affects their reserves, (The flexibility of reserves has been an important phenomenon in various markets. In auctions Smith ${ }^{[13]}$ provided a detailed account of the flexible reserves phenomenon that is quite wide-spread in fish and horse markets. In these markets, the sellersas opposed to the buyers-don't commit to a particular reserve until they have observed the bidding process. Gribbin ${ }^{[14]}$ also reported similar behaviour of agents in mineral markets. Graham and McLean ${ }^{[15]}$ explained the flexible reserves phenomenon by highlighting the learning experience of the sellers about the "types" of surviving bidders from the bidding process. The inefficiency associated with flexible reserves has also been well-documented due to a high buy-inrates ${ }^{[16]}$ one will notice a new type of asymmetry in customer markets that has been unnoticed in the literature. Actual customers have inflexible reserves while prospective customers are characterised by volatility of their reserves even though a typical firm does not engage in price changes.

We intend to examine the precise consequences of this asymmetry in this study. A representative firm in a customer market has to ex ante determine its output, but with respect to selling its output the firm can ex post choose between actual and prospective customers. The advantage of this flexibility is that the market choice can be made conditional on the realisation of the reserves of the prospective customers. When the reserves of the prospective customers have assumed high values, the firm can sell to the prospective customers at a higher price. When their reserves fall below a threshold, the firm can fall back on the actual customers. Imperfectly rational and prospective customers-with volatile reserves-thus give an option to the firm by giving flexibility to a firm's choice of customers depending on the realisation of the reserves of the prospective customers. Revenues from the actual customers are certain irrespective of volatility of reserves of the prospective customers. In this sense, the prospective customers are like an option that a rational firm would like to exploit. The sales to these prospective customers are like a European call option. In this work we explore the implications of this call option in the context of customer markets.

Formation and revision of reserves: At any date a typical seller has a finite number of buyers who form two groups. The first group consists of buyers who have learnt the rational expectations price forecast and hence, their price expectation/reserve is firm. We call them fully rational buyers. The second group consists of buyers who are still learning and their price expectation/reserve is malleable and we call them imperfectly rational. In what follows we try to explain these reserves.

Let us suppose many (large and fixed numbers) of buyers and sellers engage in a market for homogenous product. For simplification let us assume that sellers have identical cost conditions and a typical buyer's demand is qi(p) from a seller offering price $p$ such that $p \leq$ ri. Where ri is the reserve of buyer i. Buyer i makes no purchase if his reserve is less than the offer price. Due to the search cost there emerges a price distribution.

Assumption 1: It is a common and public knowledge that price offers are represented by a distribution function

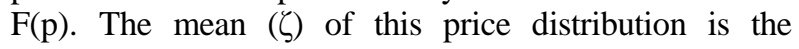
common/public price expectation of the buyers.

This is a standard assumption in search markets ${ }^{[17]}$. Buyers and sellers behave as if the distribution function, $\mathrm{F}$, is a common knowledge and a buyer incurs a cost, $\mathrm{s}_{\mathrm{c}}$, to sequentially search for the price that is no greater than his reserve that minimises the expected cost of purchase $^{[17]}$. Since our concern is primarily with price changes, we move to the next assumption.

Assumption 2: Each buyer is a repeat buyer and hence, if there is any change in current price offer; then buyer $\mathrm{i}$ anticipate a new price distribution whose mean is $u_{i}$. We assume that $\mathrm{u}_{\mathrm{i}}$ depends also on the private information of buyer i about the mean (This point has already been raised by Gaswirth ${ }^{[19]}$. He argues: if buyers' estimates of the price distribution are falsified, it dramatically increases search activities. Rothschild ${ }^{[20]}$ emphasized this possibility).

Definition 1: We define $y_{t}{ }^{i}$ as the following Eq. (1a):

$$
\zeta / u_{i}(t)=y_{t}{ }^{i}
$$

n 1: The reserve, $r_{i}(t)$, of buyer $i$ at date $t$ is given by equation (1b) where $s_{c}$ is the search cost and $\zeta$ is the mean of the price distribution Eq. (1b):

$$
\mathrm{r}_{\mathrm{i}}(\mathrm{t})=\zeta /\left(1+\mathrm{s}_{\mathrm{c}}\right)
$$

Proof: The marginal benefit $\left(\mathrm{MB}_{\mathrm{i}}\right)$ from search is given by (ignoring time script t) Eq. (1c and 1d):

$$
\begin{aligned}
& \mathrm{MB}_{\mathrm{i}}=\left(\zeta-\mathrm{u}_{\mathrm{i}} /\left(\mathrm{u}_{\mathrm{i}}\right)\right. \\
& =\mathrm{y}^{\mathrm{i}}-1
\end{aligned}
$$

Note that $\zeta$ is public information about the price distribution while $u_{i}$ is a privately held belief about the 
price distribution. Hence (1c) gives an anticipated benefit from a contrarian expectation.

The optimal search is given by the condition that costs and benefits are balanced in the margin eq. (1e):

$$
\mathrm{MB}_{\mathrm{i}}=\mathrm{s}_{\mathrm{c}}
$$

From the above condition we derive the reserve of buyer $\mathrm{i}$ at date $\mathrm{t}$ as $\mathrm{r}_{\mathrm{i}}(\mathrm{t})$ such that $\mathrm{u}_{\mathrm{i}}(\mathrm{t})=\mathrm{r}_{\mathrm{i}}(\mathrm{t})=\zeta /\left(1+\mathrm{s}_{\mathrm{c}}\right) \quad$ (1f) QED.

Assumption 3: If expectations are fulfilled at date $t$, then $u_{i}(t+1)=\zeta$. Buyers expect, at period $t$, that their price expectations at $(t+1)$ will be fulfilled. Thus, buyer $i$ expects at date $t$ that the mean of the actual distribution $\zeta$ will coincide with his expectation $u_{i}$ $(\mathrm{t}+1)$. This is a common assumption in the learning literature $^{[18]}$.

Proposition 2: If buyer i has new price observations, his reserve $r_{i}(t)$ is revised according to the updating rule (2a) where $\delta$ is a weight of the updating rule and $0<\delta<1$, $P_{t}$ is the mean of new price observations, $u_{i}(t)$ equals $r_{i}$ (t) Eq. (2a-a'):

$$
\begin{aligned}
& \mathrm{r}_{\mathrm{i}}(\mathrm{t}+1)=\left[\delta /\left(1+\mathrm{s}_{\mathrm{c}}\right)\right] \mathrm{u}_{\mathrm{i}}(\mathrm{t})+\left[(1-\delta) /\left(1+\mathrm{s}_{\mathrm{c}}\right)\right] \mathrm{P}_{\mathrm{t}} \\
& =\left[\mathrm{dr}_{\mathrm{i}}(\mathrm{t})+(1-\mathrm{d}) \mathrm{P}_{\mathrm{t}}\right] /\left(1+\mathrm{s}_{\mathrm{c}}\right)
\end{aligned}
$$

Proof: See the appendix

Proposition 3: The rational expectations equilibrium requires that a typical seller will correctly predict the evolving reserve $r_{i}(t+1)$ and will set the price $P_{t}^{e}$ which is to be correctly predicted and observed by the buyers. Thus at the rational expectations equilibrium:

$$
\mathrm{P}_{\mathrm{t}}^{\mathrm{e}}=\mathrm{r}_{\mathrm{i}}(\mathrm{t}+1)=\left[\delta /\left(\mathrm{d}+\mathrm{s}_{\mathrm{c}}\right)\right] \mathrm{u}_{\mathrm{i}}(\mathrm{t})
$$

A fully rational buyer holds the price expectations as per equation (2b).

If some buyers have different estimates of the mean of the new price observations ${ }^{[19,20]}$, then their price forecasts fail to coincide with $\mathrm{P}_{\mathrm{t}}^{\mathrm{e}}=\left[\delta /\left(\delta+\mathrm{s}_{\mathrm{c}}\right)\right] \mathrm{u}_{\mathrm{i}}(\mathrm{t})$.

Note: No Price Change at Date t: The buyer does not observe a change in offer price at Date $t$.

These buyers are imperfectly rational. As a result, the seller also fails to predict their reserves correctly. If a group of buyers j estimate $\mathrm{P}_{\mathrm{t}}^{*}$ as the mean, then their reserve is:

$$
\mathrm{r}_{\mathrm{j}}(\mathrm{t}+1)=\left[\delta /\left(1+\mathrm{s}_{\mathrm{c}}\right)\right] \mathrm{u}_{\mathrm{j}}(\mathrm{t})+\left[(1-\delta) /\left(1+\mathrm{s}_{\mathrm{c}}\right)\right] \mathrm{P}_{\mathrm{t}}^{*}
$$

Proof: See the appendix.

We now present the information dynamics and learning experiences of a typical buyer $\mathrm{i}$ in the following Fig. 1.

Price change at date t: The buyer observes changes in offer prices at Date t. The information dynamics continues at infinitum for a buyer. Until and unless a buyer observes price changes, his reserve is given by equation (if) whilst the reserve of a buyer is updated by Eq. (2a') for a buyer who observes changes in offer prices.

Volatility of reserves and customer markets: We assume that the sole source of uncertainty in the market is volatility of reserves of the prospective customers ${ }^{[21]}$. Let $\mathrm{RM}$ be the fixed and common reserve of the existing actual customers at period $\mathrm{I}$, which is the rational expectations given by (2b). Let $R_{N}$ be the unknown reserves of the prospective customers at Period II, as outlined in equation (2b'). We assume for simplicity that $\mathrm{R}_{\mathrm{N}}$ is identical for all prospective customers without any loss of generality. We further assume that the representative firm is risk averse and characterised by a von-Neumann-Morgenstern utility index U.

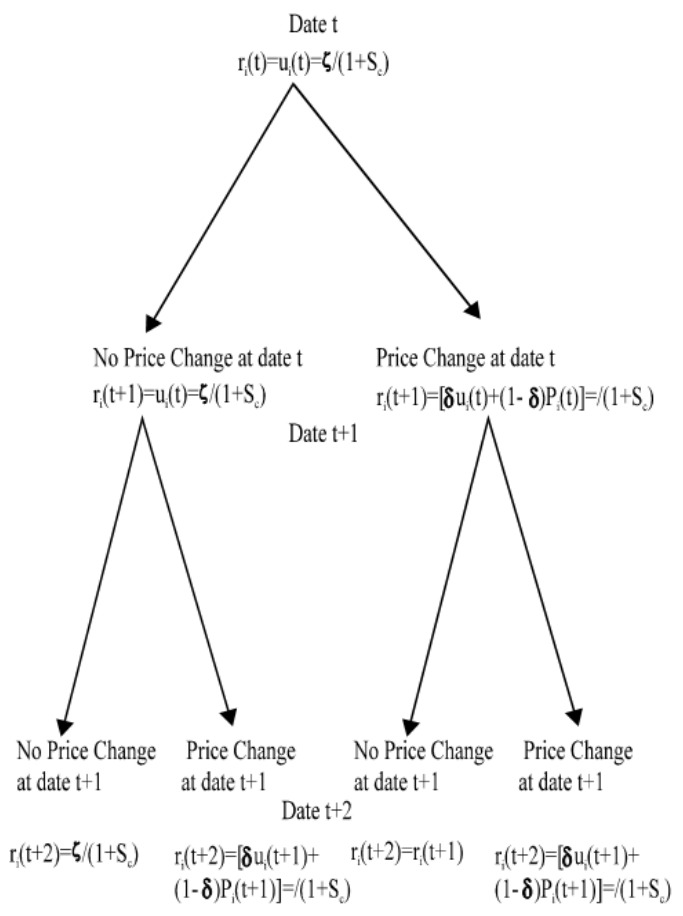

Fig. 1: Information Dynamics and Learning Experience of a Representative Buyer $\mathrm{i}$ 
The firm maximises the expected utility of its profits $\Pi$, that is, $\mathrm{E} \mathrm{U}(\Pi)$, where $\mathrm{E}($.$) is the expectational$ operator. It is further assumed that $\mathrm{U}^{\prime}>0$ and $\mathrm{U}^{\prime \prime}<0$.

Postulate 1: The common reserve of the prospective customers, $\mathrm{R}_{\mathrm{N}}$, is a random variable and given by Eq. (3a):

$\mathrm{R}_{\mathrm{N}}=\mathrm{R}_{\mathrm{N}}+\mathrm{a} \in$

With $\mathrm{E}(\epsilon)=0$ and $\operatorname{Var}(\epsilon)=1$ and $\quad \mathrm{a}>0$

where, $a$ is a shift parameter and $\in$ captures the randomness in the reserve of prospective buyers.

Postulate 2: The firm sets its output and employment at Period I. The actual customers have reserve $R_{M}$ and will buy in Period I and repeat purchase in Period II if price is unchanged. The reserve of the prospective customer realises in Period II and the firm then determines its price and allocation of sales.

The main intuition is that allocation decision can be made after the realisation of the reserve of the prospective customers giving flexibility and hence, the firm gains from the prospective customers ${ }^{[2]}$.

Postulate 3: Production technology is given as Eq. (3b):

$$
\mathrm{Y}=\mathrm{F}(\mathrm{L})
$$

With $F_{L}>0$ and $F_{L L}<0$, where $Y$ and $L$ respectively represent output and employment of the representative firm.

Writing $\mathrm{w}$ as the wage rate, profits, $\Pi$, of the representative firm at Period II are eq. (3c and 4):

$$
\begin{aligned}
& \Pi=\operatorname{Max}\left\{\mathrm{YR}_{\mathrm{N}}-\mathrm{wL}, \mathrm{YR}_{\mathrm{M}}-\mathrm{wL}\right\} \\
& \text { or, } \Pi=\operatorname{Max}\left\{\mathrm{F}(\mathrm{L}) \mathrm{R}_{\mathrm{N}}-\mathrm{wL}, \mathrm{YR}_{\mathrm{M}}-\mathrm{wL}\right\}
\end{aligned}
$$

Writing $\mathrm{S}$ as the sales to the prospective customers we arrive at the following contingency rule:

\section{Contingency rule:}

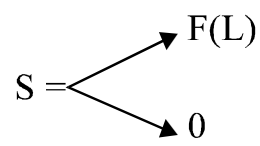

$$
\begin{aligned}
& : \mathrm{R}_{\mathrm{N}}>\mathrm{R}_{\mathrm{M}} \\
& : \mathrm{R}_{\mathrm{N}}><\mathrm{R}_{\mathrm{M}}
\end{aligned}
$$

The contingency rule implies the following: if $\mathrm{R}_{\mathrm{N}}<\mathrm{R}_{\mathrm{M}}$, the option to sell to the prospective customers is not exercised. The option is exercised otherwise. Hence, the payoff from an extra unit sold to a prospective customer is $\mathrm{R}_{\mathrm{N}}-\mathrm{R}_{\mathrm{M}}$ and zero otherwise. This is simply a European call option that gives the firm an opportunity to sell its product to the prospective customer if the reserve of the prospective customer exceeds the reserve of the actual customer (An European call option gives the option holder the right to sell a financial asset for the spot price if the spot price exceeds the exercise price). The payoff from the prospective customers is therefore similar to the payoff of a call option with exercise price $R_{M}$ with the security price $R_{N}$. The time-zero value of such an option can be found by using the standard option-price techniques. The economic problem of a representative firm.

The firm maximises its expected utility that can be reduced to the following Eq. (6):

Maximise E $U\left[\left(R_{M}+q(z) \in a z\right) f(L)-w L\right]$

where, $q(z)$ is the standard indicator function $(7 a-b)$ :

$$
\begin{aligned}
& q(z)=1 \text { if } z>0 \\
& q(z)=0 \text { if } z<0
\end{aligned}
$$

The first order condition to maximise expected utility from profits with respect to $\mathrm{L}$ is as follows Eq. (8):

$$
\begin{aligned}
& \mathrm{U} \phi\left(\Pi^{*}\right)\left[\mathrm{R}_{\mathrm{M}} \mathrm{F}_{\mathrm{L}}(\mathrm{L} *)-\mathrm{w}\right] \mathrm{v}(\in<0)+\mathrm{U} \phi(\Pi *) \\
& {\left[\left(\mathrm{R}_{\mathrm{M}}+\mathrm{a} \in\right) \mathrm{F}_{\mathrm{L}}(\mathrm{L} *)-\mathrm{w}\right] \mathrm{dv}(\in)=0}
\end{aligned}
$$

where, $\mathrm{v}(\in)$ is the probability measure of the random variable $\in$.

We now analyse the impact of volatility of reserves of the prospective customers on the output as well as on labour demand of the representative firm. Applying the implicit function theorem on the first order condition (8) we get:

$\frac{\mathrm{dL} *}{\mathrm{da}}=\frac{\Delta_{1}}{\Delta_{2}}$

Where:

$$
\begin{aligned}
& \Delta_{1}=\int_{\varepsilon>0} \varepsilon F_{L}\left(L^{*}\right) \mathrm{U}^{\prime}\left(\Pi^{*}\right)\left[\frac{\mathrm{U}^{\prime \prime}\left(\Pi^{*}\right)}{\mathrm{U}^{\prime}\left(\Pi^{*}\right)} \Pi^{*}\right. \\
& +\frac{\mathrm{U}^{\prime \prime}\left(\Pi^{*}\right)}{\mathrm{U}^{\prime}\left(\Pi^{*}\right)} \mathrm{w}\left(\mathrm{L}^{*}-\frac{\mathrm{F}\left(\mathrm{L}^{*}\right)}{\mathrm{F}_{\mathrm{L}}\left(\mathrm{L}^{*}\right)}+1\right] \mathrm{dv}(\varepsilon) \\
& \Delta_{2}=\int_{\varepsilon>0}\left[\mathrm{U}^{\prime \prime}\left(\Pi^{*}\right)\left(\mathrm{R}_{\mathrm{M}}+\mathrm{q} \varepsilon\right) \mathrm{F}_{\mathrm{LL}}\left(\mathrm{L}^{*}\right)\right] \mathrm{dv}(\varepsilon) \\
& +\left(\mathrm{R}_{\mathrm{M}} \mathrm{F}_{\mathrm{L}}(\mathrm{L} 8)-\mathrm{w}\right)^{2}+\mathrm{U}^{\prime}\left(\Pi^{*} \mathrm{R}_{\mathrm{M}} \mathrm{F}_{\mathrm{LL}}\left(\mathrm{L}^{*}\right)\right] \mathrm{v}(\varepsilon)<0
\end{aligned}
$$

From the concavity of production technology we know: 
$\mathrm{L}^{*}-\mathrm{F}\left(\mathrm{L}^{*}\right) / \mathrm{F}_{\mathrm{L}}\left(\mathrm{L}^{*}\right)<0$

Hence $\Delta_{1}<0$

$$
\text { If } \frac{-U^{\prime \prime}(\Pi) \Pi}{U^{\prime}(\Pi)}<0
$$

The left-hand side of $(11 \mathrm{c})$ is the measure of relative risk aversion. The sign of $\Delta_{1}$ depends on the degree of risk aversion. Hence, if the relative risk aversion of the representative firm is less than unity, then $\Delta_{1}<0$ and hence, $\Delta_{1} / \Delta_{2}>0$. As a result, the output and employment of the representative firm are larger: increasing volatility of reserves will have a positive impact on output and employment in the customer markets. On the other hand, if the relative risk aversion is less than unity, volatility of reserves will have an adverse impact on output and employment. For zero relative risk aversion, volatility of reserves has no impact on the outcome of the customer market ${ }^{[23]}$.

\section{CONCLUSION}

With an increase in volatility of the reserves of the prospective customers, the value of the option to sell the products to the prospective customers increases. This makes production of a firm in the customer market more profitable. Thus, the output of a firm in the customer market will go up with an increased volatility of reserves due to this increase in the value of the option. Volatility of reserves, however, increases the exposure of the concerned firm that, in turn, reduces the incentive to increase output. The net effect of this volatility critically hinges on the relative strengths of these opposing effects. We find that the degree of risk aversion of the firm will determine whether the output and employment effects of the volatility of reserves on the customer markets are positive, or otherwise. If relative risk aversion is less than unity, increasing volatility of reserves is expected to have positive effects on output and employment in customer markets. The raison d'êtra behind the counter-intuitive finding is the asymmetry in the flexibility of reserves in customer market that is the main innovation of this study. If the firm holds its price firm, actual customers may have stable reserves while some prospective customers have volatile reserves due to their interactions with other firms. Thus the upshot is that this new asymmetry provides a theoretical basis for a positive effect of volatility of reserves on output and employment in customer markets.

The volatility of reserves can be linked with macroeconomic fluctuations ${ }^{[2]}$. Alternatively, one can demonstrate how the volatility of reserves can engender problems for the existence of a Nash equilibrium wherefrom complex dynamics can evolve ${ }^{[23-23]}$. In case the volatility has serious macroeconomic effects, interesting political economy issues concerning distributional politics can emerge ${ }^{[25]}$.

\section{Appendix}

Proof of Proposition 2: Consider the prior distribution of buyer i. He expects actual price offers to be bounded within the normal distribution $\left(\mathrm{u}_{\mathrm{i}}(\mathrm{t}), \mathrm{T}_{\mathrm{i}}(\mathrm{t})\right)$. The probability density function corresponding to this normal distribution is the following:

$\left(\mathrm{u}_{\mathrm{i}}, \mathrm{T}\right)=\mathrm{g}(\mathrm{p})$

Now as he observes a set of new observations with the (normal) distribution $\left(\mathrm{P}_{\mathrm{t}}, \mathrm{h}\right)$ and the probability density function is given as:

$\left(P_{t}, h\right)=f(p)$

He updates the subjective probability $(\Omega)$ in the following Bayesian manner:

$\Omega\left(\mathrm{u}_{\mathrm{i}}(\mathrm{t}) \mid \mathrm{P}_{\mathrm{t}}\right)=\frac{\Omega\left(\mathrm{u}_{\mathrm{i}}(\mathrm{t}) \mathrm{P}_{\mathrm{t}}\right)}{\Omega\left(\mathrm{P}_{\mathrm{t}}\right)}$

$=\frac{\Omega\left(\mathrm{u}_{\mathrm{i}}(\mathrm{t})\right) \Omega\left(\mathrm{P}_{\mathrm{t}} \mid \mathrm{u}_{\mathrm{i}}(\mathrm{t})\right)}{\Omega\left(\mathrm{u}_{\mathrm{i}}(\mathrm{t}) \mathrm{P}_{\mathrm{t}}\right)+\Omega\left(\mathrm{u}_{\mathrm{i}}^{\mathrm{c}}(\mathrm{t}) \mathrm{P}_{\mathrm{t}}\right)}$

The fundamental assumption in the literature on learning is that the agent expects the new mean to be a convex combination of the old mean and the new mean (of new observations) whilst the weights are determined by the standard deviations of the old and new set of observations. This is a limiting point of the learning literature and we also assume the same. Buyer $i$ expects that actual price would be either in $\left(u_{i}, T_{i}\right)$, or in $\left(P_{t}, h\right)$. The term $u_{i}^{c}$ denotes the nonoccurrence of $u_{i}$. The intersection of these two normal distribution is assumed to take place for price $\mathrm{p}=\mathrm{L}$ such that the following is true:

$$
\Omega\left(\mathrm{u}_{\mathrm{i}} \mid \mathrm{P}_{\mathrm{t}}\right)=\frac{1}{1+\frac{\Omega\left(\mathrm{u}_{\mathrm{i}}^{\mathrm{c}} \mathrm{P}_{\mathrm{t}}\right)}{\Omega\left(\mathrm{u}_{\mathrm{i}} \mathrm{P}_{\mathrm{t}}\right)}}
$$

By definition:

$\frac{\Omega\left(u_{i}^{c} P_{t}\right)}{\Omega\left(u_{i} P_{t}\right)}=\frac{\int_{L}^{\infty} f(p) d p}{\int_{-\infty}^{L} f(p) d p+\int_{L}^{\infty} g(p) d p}$

Hence the posterior distribution of the buyer is:

$\mathrm{u}_{\mathrm{i}}(\mathrm{t}+1)=\Omega\left(\mathrm{u}_{\mathrm{i}}(\mathrm{t}) \mid \mathrm{P}_{\mathrm{t}}\right) \mathrm{u}_{\mathrm{i}}(\mathrm{t})+\left(1-\Omega\left(\mathrm{u}_{\mathrm{i}}(\mathrm{t}) \mid \mathrm{P}_{\mathrm{t}}\right) \mathrm{P}_{\mathrm{t}}\right.$ 
Am. J. Appl. Sci., 2 (13): 39-44, 2005

$$
\begin{gathered}
\frac{\int_{-\infty}^{L} f(p) d p+\int_{L}^{\infty} g(p) d p}{\int_{-\infty}^{L} f(p) d p+\int_{L}^{\infty} f(p) d p+\int_{L}^{\infty} g(p) d p} u_{i}(t) \\
+\left(1-\frac{\int_{-\infty}^{L} f(p) d p+\int_{L}^{\infty} g(P) d p}{\int_{-\infty}^{L} f(p) d p+\int_{L}^{\infty} f(p) d p+\int_{L}^{\infty} g(p) d p}\right) P_{t}
\end{gathered}
$$

$=\delta u_{i}(t)+(1-\delta) P_{t}$

It is easy to check that $0<\delta<1$. We get (2'a) by substituting (3'd) into (1'e) of date $t+1$. Q.E.D.

Proof of proposition 3: The seller knows (3'd) and sets profit maximising price $\mathrm{P}_{\mathrm{t}}^{\mathrm{e}}$ as:

$\mathrm{P}_{\mathrm{t}}^{\mathrm{e}}=\mathrm{r}_{\mathrm{i}}(\mathrm{t}+1)=\left[\delta /\left(1+\mathrm{s}_{\mathrm{c}}\right)\right] \mathrm{u}_{\mathrm{i}}(\mathrm{t})+\left[(1-\delta) /\left(1+\mathrm{s}_{\mathrm{c}}\right)\right] \mathrm{P}_{\mathrm{t}}$

$\mathrm{P}_{\mathrm{t}}^{\mathrm{e}}=\left[\delta /\left(1+\mathrm{s}_{\mathrm{c}}\right)\right] \mathrm{u}_{\mathrm{i}}(\mathrm{t})$

Equation (4a) holds if all expectations are selfconfirming and buyers correctly estimate the mean as $\mathrm{P}_{\mathrm{t}}^{\mathrm{e}}$. Now, suppose, a group of buyers $\mathrm{j}$ estimate $\mathrm{P}_{\mathrm{t}}{ }^{*}$ as the mean, then their reserve is:

$\mathrm{r}_{\mathrm{j}}(\mathrm{t}+1)=\left[\delta /\left(1+\mathrm{s}_{\mathrm{c}}\right)\right] \mathrm{u}_{\mathrm{j}}(\mathrm{t})+\left[(1-\delta) /\left(1+\mathrm{s}_{\mathrm{c}}\right)\right] \mathrm{P}_{\mathrm{t}}{ }^{*}$

Since the seller does not know $\mathrm{P}_{\mathrm{t}}{ }^{*}, \mathrm{P}_{\mathrm{t}}^{\mathrm{e}}$ fails to coincide with $r_{j}(t+1)$ and $P_{t}^{*}$ fails to be self-confirming for buyers of type $\mathrm{j}$. As an example, suppose for a buyer of group $\mathrm{j}$, $\mathrm{P}_{\mathrm{t}} *<\mathrm{P}_{\mathrm{t}}^{\mathrm{e}}$, then this buyer will not buy at price $\mathrm{P}_{\mathrm{t}}^{\mathrm{e}}$. Ceteris paribus, such changes in reserves create instability in the demand function. QED.

\section{REFERENCES}

1. Scitovsky, T., 1978. Asymmetries in economics. Scottish J. Political Econ., 25: 227-37. DOI: 10.1111/j.1467-9485.1978.tb00250.x

2. Stiglitz, J.E., 1979. Equilibrium in Product Markets with Imperfect Information. Am. Econom. Rev., Papers and Proc., 69: 339-345. http://www.jstor.org/stable/1801670

3. Kling, A., 1982. Imperfect information and price rigidity. Econom. Inquiry, 20: 143-154. DOI: 10.1111/j.1465-7295.1982.tb01147.x

4. McDonald, I.M., 1990a. Macroeconomics with a Range of Equilibria. Basil Blakwell, London.

5. McDonald, I.M., 1990b. The setting of retail prices in a customer market. Economic Record, 66: 322328. DOI: $10.1111 /$ j.1475-4932.1990.tb01737.x

6. McDonald, I.M. and K.J. Spindler, 1987. An empirical investigation of customer market analysis-a microfoundation for macroeconomics. Appl. Econom., 19: 1149-1174. DOI: $10.1080 / 00036848700000064$
7. Wolglom, G., 1982. Underemployment equilibrium with rational expectations. Q. J. Econom., 97: 89107. DOI: $10.2307 / 1882628$

8. McDonald, I.M., 1987. Customer markets, trade unions and stagflation. Economica, 54: 139-153. http://www.jstor.org/stable/2554387

9. Okun, A.M., 1981. Prices and Quantities: A MacRoeconomic Analysis. Brookings Institution Press, Washington, ISBN-10: 0815718721, pp: 367.

10. Nishimura, K., 1989. Customer markets and price sensitivity. Economica, 56: 187-198. http://www.jstor.org/stable/2554038

11. Scitovsky, T., 1952. Welfare and Competition. Allen and Unwin: London.

12. Rowe, N., 1987. An extreme keynesian macroeconomic model with formal micro-economic foundations. Can. J. Econom., 20: 306-320. http://www.jstor.org/stable/135363

13. Smith, C., 1989. Auctions: The Social Construction of Value. Harvester Wheatsheaf, London, ISBN-10: 0745006507, pp: 225.

14. Gribbin, J.A., 1989. Procedures for OCS bid adequacy: Including the Final Report of the OCS Fair Market Task Force, U.S. Department of Interior.

15. Graham, D. and R.P. McLean, 1990. Phantom bidding against heterogeneous bidders. Econom. Lett., 32: 1317. DOI: 10.1016/0165-1765(90)90043-Z

16. Ashenfelter, O., 1989. How auctions work for wine and art. J. Econom. Perspect., 3: 23-36. DOI: $10.1257 /$ jep.3.3.23

17. Burdett, K., 1990. Search Market Models: A Survey. University of Essex.

18. Gaswirth, J.L., 1976. On probabilistic models of consumer search for information. Q. J. Econom., 90: 38-50. DOI: $10.2307 / 1886085$

19. Rothschild, 1973. Models of market organization with imperfect information: A survey. J. Political Econ., 81: 1283-1307. http://www.jstor.org/stable/1830741

20. Bray, M. and D. Kreps, 1981. Rational Learning and Rational Expectations. In: Essays in Honor of Kenneth J. Arrow: Volume 2, Equilibrium Analysis, Heller, W. (Ed.), Cambridge University Press, Cambridge, ISBN-10: 0521304555, pp: 318-318.

21. Gangopadhyay, P., 2000. On the coase theorem and coalitional stability: The principle of equal relative concession. Theory Decis., 49: 179-191. DOI: $10.1023 / \mathrm{A}: 1005142606780$

22. Gangopadhyay, P., 2004. Strategic manipulation and information market microstructure. Aus. Econom. Papers, 43: 75-86. DOI: 10.1111/j.1467-8454.2004.00217.x

23. Gangopadhyay, P., 2005a. Chaotic discrimination and non-linear dynamics. Am. J. Appl. Sci., 6: 441449. DOI: 10.3844 /ajassp.2005.440.442

24. Gangopadhyay, P., 2005b. Competitive Tax Evasion and Transfer Prices. Int Game Theory Rev., 09: 347347. DOI: $10.1142 / \mathrm{S} 0219198907001448$

25. Gangopadhyay, P., 2002. Politics and Nature of Competition in Oligopolistic Markets. In: Economic Theory and International Trade: Essays in Honour of Murray C. Kemp, Woodland, A., (Ed.), Edward Elgar, ISBN-10: 1840642947, pp: 236-243. 